\title{
PENERAPAN PERILAKU ALTRUISTIK DALAM LAYANAN KONSELING INDIVIDU OLEH GURU BIMBINGAN DAN KONSELING DI SEKOLAH
}

\author{
Hengki Yandri ${ }^{1}$, Moh Kamil Fikri ${ }^{2}$, Dosi Juliawati ${ }^{3}$ \\ 1,2,3 Institut Agama Islam Negeri (IAIN) Kerinci \\ e-mail: hengki@iainkerinci.ac.id
}

\begin{abstract}
This research is motivated by the indication that counselor in schools in carrying out individual counseling services have not shown altruistic behavior. The purpose of this study is to reveal the level of implementation of altuistic behavior in individual counseling services by counselor in schools using quantitative descriptive research with a total of 74 respondents who have received individual counseling services from counselor. The results of this study reveal that the average level of application of altruistic behavior of counselors in implementing individual counseling services is in the medium category.
\end{abstract}

Keywords: Altruistic, Individual Counseling, Counselor

\begin{abstract}
Abstrak: Penelitian ini dilatarbelakangi oleh adanya indikasi guru bimbingan dan konseling di sekolah dalam melaksanakan layanan konseling individu belum memperlihatkan perilaku altruistik. Tujuan penelitian ini yaitu untuk mengungkapkan tingkat penerapan perilaku altuistik dalam layanan konseling individu oleh guru bimbingan dan konseling di sekolah menggunakan penelitian kuantitatif deskriptif dengan jumlah responden sebanyak 74 orang yang pernah mendapatkan layanan konseling individu dari guru bimbingan dan konseling. Hasil peneltian ini mengungkapkan bahwa rata-rata tingkat penerapan perilaku altruistik guru bimbingan dan konseling dalam melaksanakan layanan konseling individu berada pada kategori sedang.
\end{abstract}

Kata Kunci: Altruistik, Konseling Individu, Guru Bimbingan dan Konseling.

\section{PENDAHULUAN}

Guru Bimbingan dan Konseling/Konselor dalam konteks menjalankan perannya di sekolah harus menyediakan pelayanan yang baik dan optimal untuk seluruh siswa sesuai dengan tanggungjawabnya serta merencanakan layanan sesuai dengan kebutuhan siswa di sekolah, sehingga dengan demikian pelayanan yang diberikan kepada siswa bisa tepat sasaran dan berefek pada perubahan tingkal laku siswa ke arah yang lebih baik (Juliawati, 2016). Salah 
satu layanan Bimbingan dan Konseling (BK) yang menjadi jantung hati layanan BK yaitu layanan konseling individu karena pada layanan konseling individu di samping siswa/klien dapat menceritakan/ mengemukakan permasalahan pribadinya juga dapat menemukan jalan keluar dari permasalahan yang dihadapi, kemudian mampu mengarahkan dirinya melalui bantuan guru BK/Konselor serta tercapainya kemandirian dan perkembangan yang optimal pada klien/siswa (Yandri, 2016; Yandri \& Juliawati, 2017). Layanan konseling individu adalah proses pemberian bantuan yang dilakukan melalui wawancara Konseling oleh seorang ahli (disebut guru BK/konselor) kepada individu yang sedang mengalami suatu masalah (disebut siswa/klien) yang bermuara pada teratasinya masalah yang dihadapi klien agar terciptanya kehidupan yang efektif sehari-hari (Prayitno \& Amti, 2004).

Guru bimbingan konseling merupakan aktor utama dalam kegiatan layanan konseling individu. Beberapa hasil penelitian menunjukan bahwa kualitas pribadi konselor menjadi faktor penentu bagi pencapaian konseling yang efektif di samping faktor pengetahuan tentang dinamika perilaku dan keterampilan terepeutik atau konseling (Yusuf \& Nurihsan, 2012). Kualitas pribadi Guru BK/konselor merupakan kriteria utama dari segala aspek kepribadian yang amat penting dalam menentukan keefektifan guru BK/konselor jika dibandingkan dengan pendidikan dan latihan yang ia peroleh (Salahudin, 2012). Kepribadian guru BK/Konselor yang bisa menjadi model dan tauladan yang baik bagi siapapun khususnya siswa di sekolah akan menarik klien atau siswa untuk melaksanakan konseling dengannya. Jika tidak, maka eksistensi keberadaan konselor di tengah masyarakat maupun di sekolah tidak akan pernah diakui (Yandri, 2016).

Pribadi Guru BK/konselor yang efektif harus dilandasi motif altruistik dimana seorang Guru BK/konselor memiliki kepedulian dan lebih mendahulukan kepentingan orang lain (klien) diatas kepentingan pribadinya. Perilaku altruistik adalah tindakan individu untuk menolong orang lain tanpa adanya keuntungan langsung bagi sipenolong tersebut, karena yang diuntungkan adalah orang yang diberi pertolongan maka individu yang melakukan perilaku altruistik ini akan menyampingkan kepentinggan mereka diatas kepentingan orang lain apalagi dalam keadaan darurat (Juwirayini, 2013). Pribadi Guru BK/konselor yang altruis meletakan kebutuhan atau kepentingan klien dalam mengatasi masalahnya diatas kepentingan pribadi yang mungkin saja dihadapi ketika klien datang pada Guru BK/konselor (Santoso, 2015).

Perilaku altruistik dalam pandangan Islam dapat dijelaskan secara lengkap di dalam kandungan kitab suci Al Quran surat At Taubah ayat 71 yang artinya "dan orang-orang yang beriman, lelaki dan perempuan, sebahagian mereka (adalah) menjadi penolong bagi sebahagian yang lain. mereka menyuruh (mengerjakan) yang ma'ruf, mencegah dari yang munkar, 
mendirikan shalat, menunaikan zakat dan mereka taat pada Allah dan Rasul-Nya. mereka itu akan diberi rahmat oleh Allah; Sesungguhnya Allah Maha Perkasa lagi Maha Bijaksana". Ayat ini menjelaskan tentang perilaku altruistik yang menggambarkan bahwasannya siapapun diantara kita laki-laki maupun perempuan, individu maupun kelompok, maka dianjurkan untuk menolong orang lain dengan sukarela tanpa pamrih, beramal baik, lebih mementingkan orang lain, kesejahteraan orang lain, tanpa mengharapkan imbalan, dan tidak mementingkan diri sendiri, karakter yang di tolong diantarannya kesamaan, jenis kelamin, bentuk materi yaitu berupa benda, bentuk non materi yaitu nasehat, motivasi, doa, dan ilmu.

Selanjutnya Allah SWT berfirman dalam surat Al-Maidah ayat ke 2 yang artinya "dan tolong menolonglah kamu dalam (mengerjakan kebajikan) dan takwa, dan jangan tolong menolong dalam berbuat dosa dan pelanggaran. dan bertaqwalah kamu kepada Allah, sesungguhnya Allah amat berat siksa-Nya". Ayat tersebut menjelaskan manusia di ajarkan untuk saling menolong dan melindungi satu sama lain, agar hubungan persaudaraan dan silaturahmi tetap terjalin. Perilaku altruisme juga mendorong seorang guru BK/konselor untuk berbuat ikhlas karena Allah SWT dalam menjalankan pekerjaan dan kewajibannya sebagai seorang guru BK/Konselor. Karakteristik dari perilaku altruistik yang harus ada pada guru BK/Konselor yaitu empati, belief on a just word, social responsibility, internal loc (locus of control), dan low egocentricm (Myers dalam Searis, 2016).

Beberapa penjelasan di atas menunjukkan karakter manusia yang mempedulikan masalah dan kebutuhan orang lain merupakan kebutuhan yang harus dipenuhi dalam menjalani kehidupan sosial. Mementingkan permasalahan klien juga merupakan wujud profesional dan etika seorang guru $\mathrm{BK} /$ konselor dalam memberikan proses bantuan secara profesional bagi pengguna layanan. Namun kenyataan di lapangan, tidak sedikit para siswa/klien yang tidak mau datang ke ruang bimbingan dan konseling, bukan karena guru BK yang kurang keilmuannya dalam bidang bimbingan, tetapi karena mereka memiliki kesan bahwa guru BK tersebut bersifat judes atau kurang ramah (Yusuf \& Nurihsan, 2012). Hal ini didukung juga oleh hasil studi pendahuluan peneliti kepada beberapa orang siswa yang pernah melakukan konseling individu yang menyatakan bahwa masih ada guru BK/Konselor yang masih belum menunjukan beberapa karakteristik perilaku altruistik di dalam melaksanakan proses Konseling individu seperti kurangnya social responsibility karena guru Bimbingan Konseling/Konselor hanya memanggil beberapa siswa yang pernah melakukan kesalahan atau melanggar aturan, dan juga kurangnya low egocentricm karena pernah tidak menindak lanjuti proses konseling siswa yang di lakukan sebelumnya padahal permasalahan dari siswa belum tuntas sehingga siswa masih merasa terbebani dengan masalahnya. 
Jika perilaku altruistik ini tidak dimilki oleh seorang guru BK/konselor di sekolah, maka ada kemungkinan proses konseling individu tidak akan berjalan dengan efektif dikarenakan guru BK/Konselor tidak ikhlas dalam melayani siswa yang menjadi kliennya, padahal Rasulullah SAW perang mengingatkan dalam sebuah hadis yang diriwayatkan oleh Ibdu Hadi yang artinya "tidaklah seorang hamba yang mengikhlaskan amalnya karena Allah SWT selama empat puluh hari melainkan lahirlah sumber-sumber hikmah dari hatinya atas lisannya" (Ghazali, 2003). Jika dikaitkan dengan prilaku altruistik guru BK/konselor, maka akan terilhat jelas bahwa jika perilaku altruistik yang ditampilkan oleh guru BK/Konselor karena Allah SWT, maka hikmah-hikmah atau pertolongan Allah dalam menyelesaikan masalah siswa/kliennya akan semakin mudah. Merujuk dari hal ini, maka rumusan tujuan penelitian ini yaitu untuk mengungkapkan tingkat penerapan perilaku altuistik dalam layanan konseling individu oleh guru Bimbingan dan Konseling di sekolah.

\section{METODE}

Penelitian ini menggunakan metodologi penelitian kuantitatif deskriptif yang bertujuan untuk mendskripsikan variabel penelitian yang digunakan dalam rangka membuktikan data yang diperoleh karena adanya keragu-raguan terhadap informasi, teori kebijakan, tindakan atau produk yang telah ada (Yusuf, 2015; Sugiono, 2018). Populasi dalam penelitian ini yaitu seluruh siswa Madrasah Aliyah Negeri (MAN) 1 Kerinci yang pernah mengikuti layanan konseling perorangan dengan guru BK/Konselor yang diambil dengan cara purposif sampling, sehingga jumlah sampel dalam peneltian ini berjumlah 47 orang. Teknik pengumpulan data yang peneliti gunakan dalam penelitian ini yaitu menggunakan angket dengan skala likert dan diolah dengan rumus persentase selanjutnya dilakukan penafsiran terhadap perolehan hasil penelitian yang dilakukan untuk mendeskripsikan data tentang tingkat skor responden mengenai variabel perilaku altruistik guru BK dalam melaksankan layanan konseling individu yang dihitung dengan menggunakan skor ideal (Azwar, 2010; Juliawati \& Hengki, 2018).

\section{HASIL}

Temuan penelitian ini terkait dengan penerapan perilaku altruistik dalam layanan konseling individu oleh guru bimbingan dan konseling di sekolah akan dibagi menjadi beberapa aspek perilaku altuistik yaitu sebagai berikut: 


\section{Aspek Empati}

Gambaran perilaku altruistik guru bimbingan dan konseling di sekolah dalam melaksanakan layanan konseling individu yang berkaitan dengan aspek empati berdasarkan kriteria pengelompokan data deskriptif hasil penelitian bisa dilihat pada tabel 1 berikut:

Tabel 1. Perilaku altruistik Guru BK pada Aspek Empati

\begin{tabular}{ccc}
\hline Kategori & Frekuensi & Persentase \\
\hline Tinggi & 17 & 36,17 \\
\hline Sedang & 16 & 34,04 \\
\hline Rendah & 14 & 29,79 \\
\hline Jumlah & $\mathbf{4 7}$ & $\mathbf{1 0 0}$ \\
\hline
\end{tabular}

Dari tabel di atas dapat dilihat perilaku altruistik guru bimbingan dan konseling di sekolah dalam melaksanakan layanan konseling individu yang berkaitan dengan aspek empati menunjukkan bahwa dari 47 responden, ada sebanyak 17 orang responden menyatakan bahwa perilaku altruistik pada aspek empati guru BK/konselor berada pada kategori tinggi dengan persentase 36,17\%, kemudian 16 orang responden menyatakan bahwa perilaku altruistik pada aspek empati guru BK/konselor berada pada kategori sedang dengan persentase $34,04 \%$, dan 14 orang responden menyatakan bahwa perilaku altruistik pada aspek empati guru BK/konselor berada pada kategori rendah dengan persentase 29,79\%.

\section{Aspek Belief on a Just Word}

Gambaran perilaku altruistik guru bimbingan dan konseling di sekolah dalam melaksanakan layanan konseling individu yang berkaitan dengan aspek Belief on a Just Word berdasarkan kriteria pengelompokan data deskriptif hasil penelitian bisa dilihat pada tabel 2 berikut:

Tabel 2. Perilaku altruistik Guru BK pada Aspek Belief on a Just Word

\begin{tabular}{ccc}
\hline Kategori & Frekuensi & Persentase \\
\hline Tinggi & 17 & 36,17 \\
\hline Sedang & 20 & 42,55 \\
\hline Rendah & 10 & 21,28 \\
\hline Jumlah & 47 & $\mathbf{1 0 0}$ \\
\hline
\end{tabular}

Dari tabel 2 dapat dilihat perilaku altruistik guru bimbingan dan konseling di sekolah dalam melaksanakan layanan konseling individu yang berkaitan dengan aspek Belief on a Just Word menunjukkan bahwa dari 47 responden, ada sebanyak 17 orang responden menyatakan bahwa perilaku altruistik pada aspek Belief on a Just Word guru BK/konselor berada pada kategori tinggi dengan persentase 36,17\%, kemudian 20 orang responden menyatakan bahwa perilaku altruistik pada aspek Belief on a Just Word guru BK/konselor berada pada kategori sedang dengan persentase 42,55\%, dan 10 orang responden 
menyatakan bahwa perilaku altruistik pada aspek Belief on a Just Word guru BK/konselor berada pada kategori rendah dengan persentase $21,28 \%$.

\section{Aspek Social Responsibility}

Gambaran perilaku altruistik guru bimbingan dan konseling di sekolah dalam melaksanakan layanan konseling individu yang berkaitan dengan aspek Social Responsibility berdasarkan kriteria pengelompokan data deskriptif hasil penelitian bisa dilihat pada tabel 3 berikut:

Tabel 3. Perilaku altruistik Guru BK pada Aspek Social Responsibility

\begin{tabular}{ccc}
\hline Kategori & Frekuensi & Persentase \\
\hline Tinggi & 16 & 34,04 \\
\hline Sedang & 19 & 40,43 \\
\hline Rendah & 12 & 25,53 \\
\hline Jumlah & 47 & 100 \\
\hline
\end{tabular}

Dari tabel 3 dapat dilihat perilaku altruistik guru bimbingan dan konseling di sekolah dalam melaksanakan layanan konseling individu yang berkaitan dengan aspek Social Responsibility Word menunjukkan bahwa dari 47 responden, ada sebanyak 16 orang responden menyatakan bahwa perilaku altruistik pada aspek Social Responsibility guru BK/konselor berada pada kategori tinggi dengan persentase 34,04\%, kemudian 19 orang responden menyatakan bahwa perilaku altruistik pada aspek Social Responsibility guru BK/konselor berada pada kategori sedang dengan persentase 40,43\%, dan 12 orang responden menyatakan bahwa perilaku altruistik pada aspek Social Responsibility guru $\mathrm{BK} /$ konselor berada pada kategori rendah dengan persentase $25,53 \%$.

\section{Aspek Internal LoC (Locus of Control)}

Gambaran perilaku altruistik guru bimbingan dan konseling di sekolah dalam melaksanakan layanan konseling individu yang berkaitan dengan aspek Internal Loc berdasarkan kriteria pengelompokan data deskriptif hasil penelitian bisa dilihat pada tabel 4 berikut:

Tabel 4. Perilaku altruistik Guru bimbingan dan konseling pada Aspek Internal LoC

\begin{tabular}{ccc}
\hline Kategori & Frekuensi & Persentase \\
\hline Tinggi & 14 & 29,79 \\
\hline Sedang & 21 & 44,68 \\
\hline Rendah & 12 & 25,53 \\
\hline Jumlah & 47 & 100 \\
\hline
\end{tabular}


Dari tabel 4 dapat dilihat perilaku altruistik guru bimbingan dan konseling di sekolah dalam melaksanakan layanan konseling individu yang berkaitan dengan aspek Internal Loc menunjukkan bahwa dari 47 responden, ada sebanyak 14 orang responden menyatakan bahwa perilaku altruistik pada aspek Internal Loc guru BK/konselor berada pada kategori tinggi dengan persentase 29,79\%, kemudian 21 orang responden menyatakan bahwa perilaku altruistik pada aspek Internal Loc guru BK/konselor berada pada kategori sedang dengan persentase 44,68\%, dan 12 orang responden menyatakan bahwa perilaku altruistik pada aspek Internal Loc guru BK/konselor berada pada kategori rendah dengan persentase $25,53 \%$.

\section{Aspek Low Egocentrim}

Gambaran perilaku altruistik guru bimbingan dan konseling di sekolah dalam melaksanakan layanan konseling individu yang berkaitan dengan aspek Low Egocentrim berdasarkan kriteria pengelompokan data deskriptif hasil penelitian bisa dilihat pada tabel 5 berikut:

Tabel 5. Perilaku altruistik Guru BK pada Aspek Low Egocentrim

\begin{tabular}{ccc}
\hline Kategori & Frekuensi & Persentase \\
\hline Tinggi & 18 & 38,30 \\
\hline Sedang & 18 & 38,30 \\
\hline Rendah & 11 & 23,40 \\
\hline Jumlah & 47 & 100 \\
\hline
\end{tabular}

Dari tabel 5 dapat dilihat perilaku altruistik guru bimbingan dan konseling di sekolah dalam melaksanakan layanan konseling individu yang berkaitan dengan aspek Low Egocentrim menunjukkan bahwa dari 47 responden, ada sebanyak 18 orang responden menyatakan bahwa perilaku altruistik pada aspek Low Egocentrim guru BK/konselor berada pada kategori tinggi dengan persentase 38,30\%, kemudian 18 orang responden menyatakan bahwa perilaku altruistik pada aspek Low Egocentrim guru BK/konselor berada pada kategori sedang dengan persentase 38,30\%, dan 11 orang responden menyatakan bahwa perilaku altruistik pada aspek Low Egocentrim guru BK/konselor berada pada kategori rendah dengan persentase $23,40 \%$.

Untuk melihat gambaran penerapan perilaku altruistik dalam layanan konseling individu oleh guru bimbingan dan konseling di sekolah secara keseluruhan, bisa dilihat pada tabel 6 berikut: 
Tabel 6. Perilaku Altruistik dalam Layanan Konseling Individu oleh Guru Bimbingan dan Konseling di Sekolah

\begin{tabular}{ccc}
\hline Kategori & Frekuensi & Persentase \\
\hline Tinggi & 14 & 29,79 \\
\hline Sedang & 20 & 42,55 \\
\hline Rendah & 13 & 27,66 \\
\hline Jumlah & 47 & 100 \\
\hline
\end{tabular}

Dari tabel 6 dapat dilihat perilaku altruistik guru bimbingan dan konseling di sekolah dalam melaksanakan layanan konseling individu menunjukkan bahwa dari 47 responden, ada sebanyak 14 orang responden menyatakan bahwa perilaku altruistik guru BK/konselor berada pada kategori tinggi dengan persentase 29,79\%, kemudian 20 orang responden menyatakan bahwa perilaku altruistik guru BK/konselor berada pada kategori sedang dengan persentase 42,55\%, dan 13 orang responden menyatakan bahwa perilaku altruistik guru BK/konselor berada pada kategori rendah dengan persentase 27,66\%. Jadi dapat disimpulkan bahwa ratarata perilaku altruistik guru bimbingan dan konseling/konselor dalam melaksanakan layanan konseling individu berada pada kategori sedang, hal ini dapat dibuktikan dengan rata-rata skor perolehan responden yaitu 102,68.

\section{PEMBAHASAN}

Secara umum, rata-rata perilaku altruistik Guru BK/Konselor dalam melaksanakan layanan konseling individu berada pada tingkat kategori sedang dengan persentase 42,55\%. Secara khusus, hasil temuan penelitian menunjukkan bahwa rata-rata perilaku altruistik guru bimbingan dan konseling/konselor dalam melaksanakan layanan konseling individu pada aspek empati berada pada kategori tinggi dengan persentase 36,17\%. Salah satu kebutuhan yang mendasar didalam pelaksanaan konseling individual yang menjadikan keberhasilan didalam melaksanakan proses konseling individu yaitu seorang konselor memiliki perilaku empati yang mana dengan adanya perilaku empati konselor mampu merasakan apa yang dialami oleh seorang klien sehingga proses konseling individu berjalan dengan baik. Sikap empati merupakan kemampuan sesorang merasakan perasaan yang dialami oleh orang lain, adanya perasaan simpatik dan perhatian pada orang lain, dan seseorang yang peduli terhadap orang lain akan selalu merasakan perasaan orang lain saat suka dan duka (Cohen dalam Gatoto, 2015). Seorang guru BK/konselor harus memiliki kepribadian yang efektif dan matang dengan menunjukkan yang sikap tulus, berempati, hangat, dilandasi kasih sayang, penerimaan yang positif tanpa syarat, menunjukkan perhatian, pengertian dan dukungan, serta 
bersikap kerjasama yang baik dengan orang lain dengan memberikan penghargaan yang tinggi terhadap orang lain (Geldard \& Geldard, 2011).

Menurut Freedman, empati adalah kemampuan untuk merasakan perasaan orang lain, sikap emapatik adalah perasaan simpati dan perhatian terhadap orang lain khususnya untuk berbagi pengalaman atau secara tidak langsung merasakan penderitaan orang lain (Yudha, 2014). Kemudian hasil penelitian yang dilakukan oleh Pujiyanti (2012) mengungkapkan adanya kontribusi empati secara signifikan terhadap perilaku altruisme pada siswa siswi, dan empati memberikan kontribusi terhadap altruisme, altruisme kemungkinan dipengaruhi oleh faktorfaktor lainnya seperti suasana hati, menyakini keadilan dunia dan faktor sosiologis, secara umum, empati dan perilaku altruisme pada subjek tergolong tinggi ke arah positif. Selain itu, karakteristik kepribadian guru BK/konselor haruslah beriman dan bertakwa, menyenangi manusia, komunikator yang terampil dan mampu menjadi pendengar yang baik, memiliki ilmu dan wawasan tentang manusia; sosial budaya; dan merupakan nara sumber yang kompeten, fleksibel, tenang dan sabar, menguasai keterampilan teknik, memiliki intuisi, memahami etika profesional, respek, jujur, asli, menghargai, dan tidak menilai, empati, memahami, menerima, hangat, dan bersahabat, fasilitator dan motivator, memiliki emosi yang stabil, pikiran jernih, cepat dan mampu, objektif, rasional, logis dan kongkrit serta konsisten dan bertanggung jawab (Willis, 2007).

Selanjutnya perilaku altruistik guru BK/Konselor pada aspek Belief On a Just Word terungkap bahwa Guru BK/Konselor secara rata-rata sudah memiliki perilaku altruistik dengan kategori sedang yaitu sebesesar 42,55\%. Menolong adalah suatu sikap yang tidak bisa dipisahkan oleh seorang guru BK/konselor dengan kliennya, karena suatu kebaikan akan dibalas dengan kebaikan. Menolog seseorang hendaknya didasarkan atas dasar rasa kasih sayang, pengabdian, kesetiaan yang diberikan tanpa adanya keinginan untuk memperoleh imbalan untuk dirinya (Myer dalam Juwariyani, 2013). Munculnya perilaku menolong atau tidak menolong adalah adanya orang lain yang kebetulan berada bersama kita di tempat kejadian, semakin banyak orang lain, semakin kecil kecenderungan orang untuk menolong (Sarwono dalam Gatot, 2015). Selain perilaku menolong, kepribadian guru BK/konselor juga harus luwes, hangat, dapat diterima orang lain, terbuka, dapat merasakan penderitaan orang lain, mengenal dirinya sendiri, tidak berpura-pura, menghargai orang lain, tidak mau menang sendiri, dan objektif (Munro, Manthei \& Small, 1983)

Perilaku altruistik Guru BK/Konselor pada aspek Social Responsibility terungkap bahwa Guru BK/Konselor sudah memiliki perilaku altruistik pada aspek social responsibility pada kategori sedang dengan persentase 40,43\%. Guru BK/Konselor memiliki peran yang sangat 
penting didalam keberhasilan seorang siswa sehingga ketika ada siswa yang membutuhkan pertolongan seorang Guru BK/Konselor harus siap untuk membantu menyelesaikan permasalahan siswa yang membutuhkan pertolongan. Orang yang saling menolong mengekspresikan kepercayaan bahwa setiap individu bertanggung jawab untuk melakukan yang terbaik untuk menolong orang yang membutuhkan (Baron dalam Juwariyani, 2013). Sejalan dengan itu menurut Suyono menyatakan orang yang mempunyai kecerdasan tinggi cenderung mengerti dan sadar bahwa tindakan untuk menolong orang lain merupakan tindakan yang menjadi bagian dari aktris (Yudha, 2015). Selanjutnya Seorang Guru BK/konselor harus memiliki sikap spontan dalam membantu orang lain yang sedang membutuhkan bantuannya, memiliki penerimaan dan penghargaan diri yang positif dan peduli terhadap orang lain, memahami dan dapat merasakan apa yang dirasakan oleh orang lain dalam kehidupan kesehariannya, seorang konselor juga harus menampilkan sikap hangat serta bersedia dan bertanggungjawab menjadi model bagi kepribadian efektif, memiliki sikap jujur, tulus dan terbuka terhadap dirinya sendiri dan orang lain (Yandri, 2016)

Seterusnya perilaku altruistik Guru BK/Konselor aspek internal loc terungkap bahwa Guru BK/Konselor sudah memiliki perilaku altruistik pada aspek internal loc pada kategori sedang dengan persentase 44,68\%. Seorang guru BK/Konselor sangatlah penting mempunyai suatu kepribadian yang baik sehingga dengan adanya kepribadian yang baik pada diri seorang guru bimbingan dan konseling akan menimbulkan suatu motivasi yang baik dari siswa. Menurut Baron, kepercayaan individu bahwa individu tersebut dapat memilih untuk bertingkah laku dalam cara memaksimalkan hasil akhir yang baik dan meminimalkan yang buruk (Juwariyani, 2013). Salah satu prinsip dasar dalam penyelenggaraan pelayanan konseling yaitu prinsip integrasi pribadi yang menekankan keutuhan pribadi dengan segenap kelebihan dan kekurangannya dalam menyelanggarakan layanan konseling individu (Prayitno, 2009).

Kemudian perilaku altruistik Guru BK/Konselor pada aspek low egocentricm terungkap bahwa Guru BK/Konselor sudah memiliki perilaku altruistik pada aspek low egocentricm pada kategori sedang dengan persentase 38,30\%. Guru BK/Konselor didalam menjalankan tugasnya harus selalu mementingkan kewajibannya terhadap siswa didiknya sebagai tanggung jawabnya sebagai guru bimbingan dan konseling, karena jika seorang Guru BK/Konselor didalam melaksanakan tugasnya selalu mementingkan kebutuhan pribadinya maka kegiatan dan program yang telah dibuat oleh seorang guru BK/Konselor tidak akan terlaksana dengan baik dan akan membuat siswa yang di asuhnya merasa kecewa, oleh karena itu sangat amat penting bagi seorang guru bimbingan dan konseling lebih mengutamakan kepentingan siswanya. Orang yang 
mengalami suasana hati gembira akan lebih suka menolong, sedangkan dalam suasana hati yang sedih orang kurang suka memberikan pertolongan (Taylor dalam Yudha, 2015).

\section{PENUTUP}

Hasil penelitian ini menunjukkan bahwa rata-rata guru BK dalam melaksanakan layanan konseling individu sudah memiliki perilaku altruistik dengan tingkat kategori sedang. Namun demikian, masih ada sebagain responden yang memberikan pernyataan bahwa guru BK belum menunjukkan perilaku altruistik terkait dengan aspek empati, belief on a just word, social responsibility, internal locus of control, dan low egocentricm. Penelitian ini diharapkan dapat bermanfaat bagi keilmuan bimbingan dan konseling dalam membantu guru BK melaksanakan layanan konseling individu dengan menampilkan perilaku altruistik secara optimal.

\section{REFERENSI}

Al Ghazali, I. (2003). Ibya Ulumuddin. Semarang: Asy syifa.

Azwar, S. (2010). Penyusunan Skala Psikologi. Yogyakarta: Pustaka Pelajar

Gatot, S. (2015). Hubungan tingkat religiusitas dengan perilaku altruistik pada santri di pondok pesantren Futubiyyah Mranggen Kab. Demak (Skripsi, Universitas Islam Negeri Walisongo).

Geldard, K \& Geldard, D. (2011). Keterampilan Praktik Konseling; Pendekatan Integratif. Alih bahasa: Eva Hamdiah. Yogyakarta: Pustaka Pelajar

Juliawati, D. (2016). Peran Guru Bimbingan dan Konseling/Konselor dalam Mengurangi Tingkat Prokrastinasi Akademik Siswa di Sekolah. Tarbawi: Jurnal Ilmu Pendidikan, 1(2).

Juliawati, D., \& Yandri, H. (2018). Prokrastinasi Akademik Mahasantri Ma'had Al Jami'ah IAIN Kerinci. Jurnal Fokus Konseling, 4(1), 19-26.

Juwariyani, P. (2013). Hubungan kebermaknaan bidup dengan perilaku altruistik pada mahasiswa Fakultas Psikologi Universitas Islam Negeri Maulana Malik Ibrabim Malang (Skripsi, Universitas Islam Negeri Maulana Malik Ibrahim).

Munro, E.A., Manthei, R.J \& Smalll, J.J. (1983). Penyuluhan: Suatu Pendekatan Berdasarkan Keterampilan. Alih bahasa: Erman Amti. Jakarta: Ghalia Indonesia.

Prayitno dan Amti, E. (2004). Dasar-Dasar Bimbingan dan Konseling. Jakarta: Rineka Cipta

Prayitno. 2009. Wawasan Profesional Konseling. Padang: UNP 
Pujiyanti, A. (2012). Kontribusi Empati Terhadap Perilaku Altruisme Pada Siswa Siswi SMA Negeri 1 Setu Bekasi. (Skripsi, Universitas Ghunadharma).

Salahudin, A. (2012). Bimbingan dan Konseling. Bandung: Pustaka Setia

Santoso, dkk. (2015). Life Model dalam Internalisasi Nilai-Nilai Karakter Peduli Sosial, Tanggung Jawab dan Bersahabat Pada Siswa: Jawa Timur PD ABKIN

Searis, N. (2016). Perbedaan Kecerdasan Moral dan Perilaku Altruisme Siswa yang Tinggal di Pesantren dan Non Pesantren di Madrasah Tsanawiyah Negeri 2 Kediri (Skripsi, Universitas Islam Negeri Malang)

Sugiono. (2018). Metode Penelitian Kuantitatif. Bandung: Alfabeta

Sujadi, E. (2018). Kode Etik Profesi Konseling Serta Permasalahan dalam Penerapannya. Tarbawi: Jurnal Ilmu Pendidikan, $14 \quad$ (2), 69-77. doi:10.32939/tarbawi.v14i2.298

Willis, S. S. (2007). Konseling Individual, Teori dan Praktik. Bandung: Alfabeta.

Yandri, H. (2016). Kepribadian Konselor dan Pembentukan Karakter Siswa di Sekolah. Tarbawi: Jurnal Ilmu Pendidikan, 1(1).

Yandri, H. (2016). Penerapan Sugesti pada Layanan Konseling Perorangan dalam Mengurangi Perilaku Merokok pada Siswa Di Sekolah. Tarbawi: Jurnal Ilmu Pendidikan, 1(2).

Yandri, H., \& Juliawati, D. (2017). Burnout pada Guru BK/Konselor Sekolah. Konselor, 6(2), 61-65.

Yudha, T. I. (2014). Hubungan antara Kematangan Beragama dengan Perilaku Altruistik Siswa di SMK Negeri Temayang Bojonegoro (Skripsi, Universitas Islam Negeri Maulana Malik Ibrahim).

Yusuf, A. M. (2005). Metodologi Penelitian. Padang: UNP Press

Yusuf, S \& Nurihsan, J. A. (2012). Landasan Bimbingan dan Konseling. Bandung: Remaja Rosdakarya 